\title{
Study of Possible Mechanisms Involved in the Inhibitory Effects of Coumarin Derivatives on Neutrophil Activity
}

\author{
Katarína Drábiková, ${ }^{1}$ Tomáš Perečko, ${ }^{1}$ Radomír Nosál', ${ }^{1}$ Juraj Harmatha, ${ }^{2}$ \\ Jan Šmidrkal, ${ }^{3}$ and Viera Jančinová ${ }^{1}$ \\ ${ }^{1}$ Institute of Experimental Pharmacology and Toxicology Slovak Academy of Sciences, Dúbravská cesta 9, \\ 84104 Bratislava, Slovakia \\ ${ }^{2}$ Institute of Organic Chemistry and Biochemistry, Academy of Sciences of the Czech Republic, v. v. i., \\ Flemingovo náměsti 2, 16110 Prague, Czech Republic \\ ${ }^{3}$ Institute of Chemical Technology Prague, Technická 5, 16628 Prague, Czech Republic
}

Correspondence should be addressed to Katarína Drábiková; katarina.drabikova@savba.sk

Received 22 July 2013; Revised 17 October 2013; Accepted 17 October 2013

Academic Editor: David Vauzour

Copyright ( 2013 Katarína Drábiková et al. This is an open access article distributed under the Creative Commons Attribution License, which permits unrestricted use, distribution, and reproduction in any medium, provided the original work is properly cited.

\begin{abstract}
To specify the site of action of the synthetic coumarin derivatives 7-hydroxy-3-(4'-hydroxyphenyl) coumarin (HHC) and 7hydroxy-3-(4'-hydroxyphenyl) dihydrocoumarin (HHDC), we evaluated their effects on extra- and intracellular reactive oxygen species (ROS) formation in phorbol-myristate-13-acetate (PMA) stimulated human neutrophils. We studied also the effects of HHC and HHDC on possible molecular mechanisms which participate in the activation of NADPH oxidase, that is, on PKC activity, on phosphorylation of some PKC isoforms $(\alpha, \beta \mathrm{II}$, and $\delta)$, and on phosphorylation of the NADPH oxidase subunit p40 ${ }^{p h o x}$. Without affecting cytotoxicity, both coumarines tested were effective inhibitors/scavengers of ROS produced by neutrophils on extracellular level. HHC markedly diminished oxidant production and also, intracellularly, decreased PKC activity and partly phosphorylation of PKC $\alpha, \beta$ II. On the other hand, we did not observe any effect of coumarin derivatives on phosphorylation of PKC $\delta$ and on phosphorylation of the NADPH oxidase subunit $\mathrm{p} 40^{\text {phox }}$, which were suggested to be involved in the PMA-dependent intracellular activation process. In agreement with our previous findings, we assume that the different molecular structures of HHC and HHDC with their different physicochemical and free radical scavenging characteristics are responsible for their diverse effects on the parameters tested.
\end{abstract}

\section{Introduction}

Neutrophils are key cells of the first line of defense, but they are also considered potent inflammatory cells causing tissue damage. Thus the ability of compounds which prevent extensive and potentially dangerous activation of neutrophils has been proposed as an important injury-limiting way. Coumarins belong to the group of plant-derived polyphenolic compounds possessing broad biochemical and pharmacological effects, like anti-HIV, anti-inflammatory, antioxidant, antibacterial, anticoagulant, and anticancer activities [1-4]. Over the last years, natural as well as synthetic coumarins were extensively studied and many of them are considered attractive candidates in therapeutic development.
Production of reactive oxygen species (ROS) in neutrophils and other phagocytic cells is linked to the activation of NADPH oxidase, a multiprotein enzyme complex, which plays an essential role in innate immunity. Yet excessive ROS generation by phagocytes is involved in tissue injury associated with a number of chronic inflammatory diseases [5-7]. In resting cells, NADPH oxidase is inactive and its components are distributed between the cytosol and membranes. When cells are activated, the cytosolic components $\left(\mathrm{p} 40^{\text {phox }}, \mathrm{p} 47^{\text {phox }}, \mathrm{p} 67^{\text {phox }}\right.$, and Rac2) migrate to the membranes, where they associate with the membranebound component (flavocytochrome b558) to assemble the catalytically active NADPH oxidase, resulting in the delivery of ROS into the extracellular environment or inside into the 
phagocytic vesicle [8-10]. NADPH oxidase is also activated within specific intracellular compartments, leading to an intracellular ROS production which may have a direct role in signal transduction. It was reported that the cytosolic component of the NADPH oxidase, $\mathrm{p} 40^{\text {phox }}$, associates with cytochrome b, especially in intracellular membranes [10-13]. Localisation of neutrophil ROS production and its possible regulation thus play an important role in the development of effective treatments to control the damage associated with chronic inflammation $[8,14]$.

Protein kinase $\mathrm{C}$ (PKC) has been shown to activate NADPH oxidase in several types of cells, such as phagocytes, cardiomyocytes, aortic endothelial cells, vascular smooth muscle cells, and renal mesangial cells [15, 16]. Various PKC isoforms have been shown to stimulate superoxide production, including $\alpha, \beta, \delta, \varepsilon$, and $\zeta[17,18]$. Neutrophils are strongly activated by PKC activating phorbol esters, which together with the expression of several PKC isoforms in neutrophils suggest a role for PKC in neutrophil functions [19]. Human neutrophils contain multiple isotypes of PKC, including $\mathrm{Ca}^{2+} / \mathrm{DG}$-dependent isotypes- $\alpha$; alternatively spliced $\beta \mathrm{I}$ and $\beta \mathrm{II} ; \mathrm{Ca}^{2+}$-independent/DG-dependent isotype $\delta$; and phosphatidylserine-dependent $\mathrm{Ca}^{2+} / \mathrm{DG}$-independent $\xi[19$, 20]. In cell-free systems, $\operatorname{PKC} \alpha, \beta$, and $\delta$ are implicated as regulators of NADPH oxidase and superoxide generation [21]. Moreover, PKC $\delta$ has been suggested to be responsible for intracellular ROS generation in PMA activated neutrophils [22].

Previously, we compared the effect of 7-hydroxy-3( $4^{\prime}$-hydroxyphenyl) coumarin (HHC) and 7-hydroxy-3- $\left(4^{\prime}-\right.$ hydroxyphenyl) dihydrocoumarin (HHDC) on stimulated phagocyte functions with their physicochemical characteristics and free radical scavenging activities in chemical assays [23].

To specify the site of action of the synthetic coumarin derivatives HHC and HHDC (Figure 1), we evaluated their effects on extra- and intracellular ROS formation in PMA stimulated human neutrophils. We also studied the effects of $\mathrm{HHC}$ and HHDC on possible molecular mechanisms which participate in the activation of NADPH oxidase: on PKC activity, phosphorylation of some PKC isoforms $(\alpha, \beta \mathrm{II}$, and $\delta)$, and on phosphorylation of the subunit $\mathrm{p} 40^{\text {phox }}$.

\section{Material and Method}

Phorbol-myristate-13-acetate (PMA), luminol (5-amino2,3-dihydro-1,4-phthalazinedione), isoluminol (6-amino2,3-dihydro-1,4-phthalazinedione), superoxide dismutase, dextran (average MW 464.000), and protease inhibitor cocktail: $104 \mathrm{mmol} / \mathrm{L}$ AEBSF [4-(2-aminoethyl) benzenesulfonyl fluoride hydrochloride], $0.085 \mathrm{mmol} / \mathrm{L}$ aprotinin, $1.53 \mathrm{mmol} / \mathrm{L}$ bestatin hydrochloride, $1.40 \mathrm{mmol} / \mathrm{L}$ E-64 [N(trans-epoxysuccinyl)-L-leucine 4-guanidinobutylamide], $1.90 \mathrm{mmol} / \mathrm{L}$ leupeptin hemisulfate salt, and $4.22 \mathrm{mmol} / \mathrm{L}$ pepstatin in DMSO, were purchased from Sigma-Aldrich Chemie (Deisenhofen, Germany), horse radish peroxidase (HRP) and catalase from Merck (Darmstadt, Germany), and
Lymphoprep (density $1.077 \mathrm{~g} / \mathrm{mL}$ ) from Nycomed Pharma AS (Oslo, Norway).

HHC and HHDC were kindly provided by Dr. Juraj Harmatha from the Institute of Organic Chemistry and Biochemistry, AV ČR, Prague, Czech Republic, and Professor Jan Šmidrkal from the Institute of Chemical Technology, Department of Dairy and Fat Technology, AV ČR, Prague, Czech Republic.

HHC $(1.27 \mathrm{mg})$ was dissolved in a mixture of $20 \mu \mathrm{L} 1$ $\mathrm{NaOH}$ and $980 \mu \mathrm{L}$ Tyrode solution (Tyrode solution consisted of $136.9 \mathrm{mmol} / \mathrm{L} \mathrm{NaCl}, 2.7 \mathrm{mmol} / \mathrm{L} \mathrm{KCl}, 11.9 \mathrm{mmol} / \mathrm{L}$ $\mathrm{NaHCO}_{3}, 0.4 \mathrm{mmol} / \mathrm{L} \mathrm{NaH} \mathrm{PO}_{4} \cdot 2 \mathrm{H}_{2} \mathrm{O}, 1 \mathrm{mmol} / \mathrm{L} \mathrm{MgCl}_{2}$. $6 \mathrm{H}_{2} \mathrm{O}$, and $5.6 \mathrm{mmol} / \mathrm{L}$ glucose, $\mathrm{pH} 7.4$ ). The stock solution $(5 \mathrm{mmol} / \mathrm{L})$ was further diluted with Tyrode solution to give $\mathrm{HHC}$ samples, concentrations $0.01-100 \mu \mathrm{mol} / \mathrm{L}$. The corresponding final concentrations of $\mathrm{NaOH}$ were $0.4-$ $400 \mu \mathrm{mol} / \mathrm{L}$; at these concentrations, the solvent agent alone did not reduce the activity and viability of neutrophils.

All other chemicals of analytical grade were from available commercial sources.

This work was approved by the Local Ethic Committee, Institute of Experimental Pharmacology and Toxicology SAS.

2.1. Blood Collection and Isolation of Human Neutrophils. Fresh blood was taken at the blood bank from healthy volunteers (men, aged 20 to 50 years) by antecubital venipuncture and was immediately mixed with $3.8 \% \mathrm{v} / \mathrm{w}$ trisodium citrate, in the ratio of $9 \mathrm{~mL}$ of blood to $1 \mathrm{~mL}$ of citrate, in polypropylene centrifugation tubes. Erythrocytes were allowed to sediment in $3 \%$ dextran solution $(1 \times \mathrm{g}, 25 \mathrm{~min}$, $22^{\circ} \mathrm{C}$ ) and neutrophils were separated by gradient centrifugation on Lymphoprep $\left(500 \times \mathrm{g}, 30 \mathrm{~min}, 22^{\circ} \mathrm{C}\right)$. After hypotonic lysis of contaminating erythrocytes, neutrophils were washed and resuspended in calcium- and magnesium-free phosphate buffer saline in mmol/L: $137 \mathrm{NaCl}, 2.7 \mathrm{KCl}, 8.1 \mathrm{Na}_{2} \mathrm{HPO}_{4}$, $1.5 \mathrm{KH}_{2} \mathrm{PO}_{4}$, and $\mathrm{pH} 7.4$, at final concentration of $1 \times$ $10^{7}$ cells $/ \mathrm{mL}$. The obtained cell suspension contained more than $96 \%$ viable cells, as evaluated by trypan blue exclusion $[24,25]$. Prior to neutrophil activation studies, the cells were resuspended in phosphate buffer saline (PBS) in $\mathrm{mmol} / \mathrm{L}$ : $137 \mathrm{NaCl}, 2.7 \mathrm{KCl}, 8.1 \mathrm{Na}_{2} \mathrm{HPO}_{4}, 1.5 \mathrm{KH}_{2} \mathrm{PO}_{4}, 1.8 \mathrm{CaCl}_{2}, 0.5$ $\mathrm{MgCl}_{2} \cdot 6 \mathrm{H}_{2} \mathrm{O}$, and $\mathrm{pH} 7.4$.

2.2. Chemiluminescence Assay of Isolated Neutrophils. The effect of HHC or HHDC (0.01, 0.1, 1, 10, and $100 \mu \mathrm{mol} / \mathrm{L})$ on extra- and intracellular ROS production was measured in unstimulated and PMA $(0.05 \mu \mathrm{mol} / \mathrm{L})$ stimulated neutrophils $\left(5 \times 10^{5} /\right.$ sample $)$ by isoluminol-/luminol-enhanced chemiluminescence (CL). Extracellular CL was determined in the system containing isoluminol $(5 \mu \mathrm{mol} / \mathrm{L})$ and $\mathrm{HRP}(8 \mathrm{U} / \mathrm{mL})$. Intracellular CL was measured with luminol ( $5 \mu \mathrm{mol} / \mathrm{L})$ in the presence of the extracellular scavengers superoxide dismutase $(100 \mathrm{U} / \mathrm{mL})$ and catalase $(2000 \mathrm{U} / \mathrm{mL})$. CL was evaluated in a microplate luminometer Immunotech LM-01T (Czech Republic) at $37^{\circ} \mathrm{C}$. Data were based on integral values of CL over 1800 s, (RLU × s; RLU: relative light units) [26, 27]. 
2.3. Chemiluminescence Assay in Cell-Free System. In the cellfree system, luminol, horseradish peroxidase, and hydrogen peroxide were used for chemiluminescence generation [28]. The $200 \mu \mathrm{L}$ samples consisted of $50 \mu \mathrm{L}$ aliquots: HRP $(2 \mathrm{U} / \mathrm{mL})$, luminol $(10 \mu \mathrm{mol} / \mathrm{L}), \mathrm{HHC}$, or HHDC solutions in the concentrations of 1,10 , or $100 \mu \mathrm{mnol} / \mathrm{L}$. The reaction was initiated by adding hydrogen peroxide at the final concentration of $100 \mu \mathrm{mol} / \mathrm{L}$. The chemiluminescence responses were measured for 10 minutes at $37^{\circ} \mathrm{C}$ in a microplate luminometer Immunotech LM-01T (Czech Republic).

2.4. PKC Activity Assay. PKC activity in the cytosol was detected by the modified method of Varga et al. [29]. Isolated human neutrophils $\left(5 \times 10^{5} / \mathrm{mL}\right)$ were incubated 30 min with $\mathrm{HHC}(1,10$, and $100 \mu \mathrm{mol} / \mathrm{L})$ or $\operatorname{HHDC}(1,10$, and $100 \mu \mathrm{mol} / \mathrm{L})$ at $37^{\circ} \mathrm{C}$. Neutrophils were then stimulated with PMA $(0.15 \mu \mathrm{mol} / \mathrm{L}$, final concentration $)$ at $37^{\circ} \mathrm{C}$ for $3 \mathrm{~min}$. The reaction was stopped by addition of $10 \mathrm{vol}$ of ice-cold PBS. After centrifugation $\left(500 \times \mathrm{g}, 4^{\circ} \mathrm{C}, 10 \mathrm{~min}\right)$ the cells were resuspended in sample buffer $(20 \mathrm{mmol} / \mathrm{L}$ TRIS-HCl, $5 \mathrm{mmol} / \mathrm{L}$ EDTA, $1 \%$ Triton, $10 \%$ glycerol, and protease inhibitor cocktail), sonicated on ice, and centrifuged $\left(14000 \times \mathrm{g}, 5 \mathrm{~min}, 4^{\circ} \mathrm{C}\right)$. The cytosolic fractions were transferred to a prechilled $1.5 \mathrm{~mL}$ microcentrifuge tube and stored at $-70^{\circ} \mathrm{C}$. Protein content of cytosol fraction was measured using Bradford Dye Reagent Detection Kit (Bio-Rad, USA). PKC activity was measured with a Nonradioactive Protein Kinase Assay kit (Assay Designs, Ann Arbor, MI, USA), which is based on a solid-phase enzyme-linked immunoabsorbent assay (ELISA), utilising a specific synthetic peptide as substrate for $\mathrm{PKC}$ and a polyclonal antibody recognizing the phosphorylated form of the substrate. The assay is developed with tetramethylbenzidine substrate and a colour develops in proportion to PKC phosphotransferase activity. The colour development was stopped with acid stop solution and the intensity of the colour was measured in a microplate reader at $450 \mathrm{~nm}$. The data were expressed as relative kinase activity per $1 \mathrm{mg}$ of protein.

2.5. Western-Blot Analysis. Phosphorylation of PKC isoenzymes $\alpha, \beta \mathrm{II}$, and $\delta$, as well as NADPH oxidase subunit $\mathrm{p} 40^{\text {phox }}$, was detected using the method described by Jančinová et al. [24, 27].

The suspension of isolated neutrophils $(100 \mu \mathrm{L})$ containing $5 \times 10^{6}$ cells was preincubated at $37^{\circ} \mathrm{C}$ for 60 seconds with different concentrations of HHC or HHDC $(10,100 \mu \mathrm{mol} / \mathrm{L})$ prior to addition of PMA $(0.15 \mu \mathrm{mol} / \mathrm{L})$. Incubation with PMA (5 min) was stopped by using a solubilisation buffer (20 mmol/L Tris-HCl, $5 \mathrm{mmol} / \mathrm{L}$ EDTA, $1 \%$ Triton, $10 \%$ glycerol, $10 \mathrm{mmol} / \mathrm{L} \mathrm{NaF}, 1 \mathrm{mmol} / \mathrm{L}$ sodium orthovanadate, $208 \mu \mathrm{mol} / \mathrm{L}$ AEBF, $0.17 \mu \mathrm{mol} / \mathrm{L}$ aprotinin, $8 \mu \mathrm{mol} / \mathrm{L}$ bestatin, $2.8 \mu \mathrm{mol} / \mathrm{L} \mathrm{E}-64,4 \mu \mathrm{mol} / \mathrm{L}$ leupeptin, and $\mathrm{pH}$ 7.4). The suspension was sonicated at $4{ }^{\circ} \mathrm{C}$ for 20 minutes and centrifuged at $14000 \times \mathrm{g}$ at $4^{\circ} \mathrm{C}$ for $5 \mathrm{~min}$ to remove unbroken cells. The supernatant was taken for measuring total protein by using Bradford Dye Reagent Detection Kit from Bio-Rad and for blotting assay. The supernatant for blotting assay was boiled for $5 \mathrm{~min}$ with sample buffer $(50 \mathrm{mmol} / \mathrm{L}$ Tris$\mathrm{HCl}, 2 \% \mathrm{SDS}, 7.5 \%$ glycerol, $2.5 \%$ mercaptoethanol, $0.01 \%$ bromophenol blue, and pH 6.8) and samples were loaded on $9.8 \%$ SDS polyacrylamide gels. Proteins ( $20 \mu \mathrm{g}$ per lane) were separated by electrophoresis and transferred to ImmobilonP Transfer Membrane (Millipore Corp., USA). From the two strips taken, one was detected for PKC $\alpha$, $\beta$ II (area between 60 and $100 \mathrm{kD}$ ) and the second for detection of $\beta$-actin (30-60 kD), which represented the internal control. Membrane strips were blocked for $60 \mathrm{~min}$ with $1 \%$ bovine serum albumin in Tris buffered saline (TBS: $20 \mathrm{mmol} / \mathrm{L}$ Tris$\mathrm{HCl}, 154 \mathrm{mmol} / \mathrm{L} \mathrm{NaCl}, 0.05 \%$ Tween-20, and $\mathrm{pH} 7.5)$. This was then followed by $60 \mathrm{~min}$ incubation in the presence of the primary antibodies: anti-phospho-PKC- $\alpha, \beta$ II (Thr638/641) (1:5000) or $\beta$-actin (rabbit anti-human, 1:4 000) (Cell Signaling Technology, Danvers, MA, USA). The membranes were subsequently washed six times with TBS and incubated $60 \mathrm{~min}$ with the secondary antibody conjugated to horseradish peroxidase (anti-rabbit from donkey, 1:5000, GE Healthcare Life Sciences, Little Chalfont, UK), and the activity of horseradish peroxidase of the bands corresponding to individual PKC isoforms was visualised using Enhanced Chemiluminescence Western Blotting Detection Reagents (GE Healthcare Life Sciences, Little Chalfont, UK).

NADPH oxidase subunit $40^{p h o x}$ and PKC isoenzyme $\delta$ were detected in the same blots after their washing and incubation with 10x diluted stripping buffer (Reblot Plus Mild Solution, Millipore, Temecula, CA, USA) for $15 \mathrm{~min}$ and washed overnight in diluent buffer ( $1 \%$ bovine serum albumin in Tris buffered saline). This was followed by 60 min incubation in the presence of primary antibodies: anti-phospho-p40 phox (T154) (1:5000) or PKC $\delta$ (Thr505) $(1: 1000)$ (Cell Signaling Technology, Danvers, MA, USA). The membranes were subsequently washed six times with TBS and incubated 60 min with the secondary antibody conjugated to horseradish peroxidase (anti-rabbit from donkey, 1:5000, GE Healthcare Life Sciences, Little Chalfont, UK), and the activity of horseradish peroxidase of the bands corresponding to the individual NADPH oxidase subunit or to PKC isoform was visualised using Enhanced Chemiluminescence Western Blotting Detection Reagents (GE Healthcare Life Sciences, Little Chalfont, UK). Autoradiogram bands were quantified using the Image J programme. The optical density of each PKC or NADPH oxidase band was corrected by the optical density of the corresponding $\beta$-actin band $[24,27]$.

2.6. Measurement of Cytotoxicity. The cytotoxic effect of HHC and HHDC was evaluated by means of ATP liberation by the luciferin-luciferase chemiluminescence. The neutrophil suspension $(30 \mu \mathrm{L} ; 30000$ cells/sample) and $20 \mu \mathrm{L}$ of Tyrode's solution were incubated with $50 \mu \mathrm{L}$ of $\mathrm{HHC}$ or HHDC $(1-100 \mu \mathrm{mol} / \mathrm{L})$ for $15 \mathrm{~min}$ at $37^{\circ} \mathrm{C}$. Ten microliters of a mixture of luciferin $(1.6 \mu \mathrm{g} / \mathrm{sample})$ and luciferase (45000 U/sample) was added, and the chemiluminescence was recorded for $60 \mathrm{~s}$. In each experiment, the chemiluminescence of ATP standards $(1-500 \mathrm{nmol} / \mathrm{L})$ was measured and the concentrations of ATP in samples were calculated from 


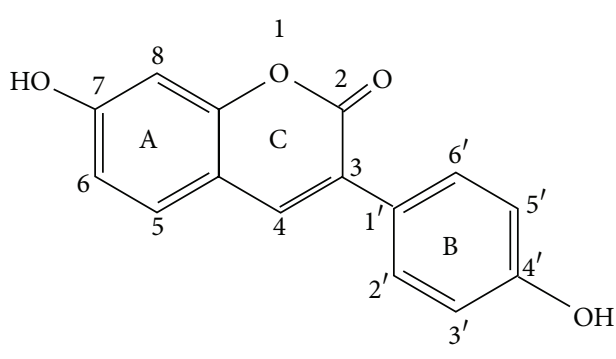

(a)

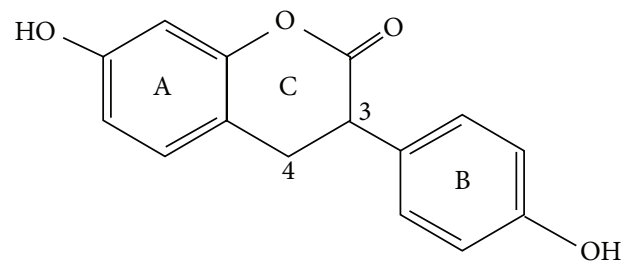

(b)

FIGURE 1: Chemical structure of synthetic phenylcoumarin derivatives related to the natural 7-hydroxycoumarin (umbelliferon). (a) 7Hydroxy-3-(4'-hydroxyphenyl) coumarin (HHC). (b) 7-Hydroxy-3-(4'-hydroxyphenyl)-3,4-dihydrocoumarin (HHDC).

the calibration curve. The total ATP content was assessed immediately after sonication of neutrophils for $10 \mathrm{~s}[24,27]$.

2.7. Statistical Analyses. All values are given as means of 48 experiments \pm SEM. Statistical significance of differences between means was established by Student's $t$-test and $P$ values below 0.05 were considered statistically significant.

\section{Results}

3.1. Effects of HHC and HHDC on ATP Liberation. To determine cytotoxicity of HHC and HHDC, we tested their effect on ATP liberation (Table 1). In the concentrations of 1, 10, and $100 \mu \mathrm{mol} / \mathrm{L}$, these compounds did not increase spontaneous ATP liberation $(12.6 \pm 0.9 \mathrm{nmol} / \mathrm{L}$ ATP), representing $7.6 \%$ of the total ATP content $(158.7 \pm 12.1 \mathrm{nmol} / \mathrm{L}$ ATP $)$, as determined immediately after complete neutrophil destruction. The results indicate that treatment with increasing concentrations of HHC and HHDC did not cause neutrophil damage.

\subsection{Effects of HHC and HHDC on Extra- and Intracellular} Chemiluminescence of Neutrophils. For activation of isolated human neutrophils, the soluble stimulus PMA was used, which bypasses receptors and activates NADPH oxidase via redistribution of $\mathrm{PKC}$ and phosphorylation of several proteins. As mentioned above, PMA is useful in investigating signal transduction pathways leading to NADPH-oxidase activation in plasma (extracellular) and granule membranes (intracellular) [10, 11]. Figure 2 demonstrates kinetics of extra- and intracellular ROS generation in isolated human neutrophils after PMA stimulation. The extracellular ROS generation was much more intensive and reached the maximum sooner than did the intracellular ROS generation. The ratio between extra- and intracellular ROS generation was approximately $10: 1$ (12 696 RLU : 1295 RLU).

Figure 3 shows that both compounds, HHC and HHDC, in the concentration scale of $0.01-100 \mu \mathrm{mol} / \mathrm{L}$, decreased significantly extracellular ROS production, as measured by chemiluminescence. The concentrations of $\mathrm{HHC}$ and HHDC producing $50 \%$ inhibition $\left(\mathrm{IC}_{50}\right)$ of control extracellular chemiluminescence were $1.04 \pm 0.20 \mu \mathrm{mol} / \mathrm{L}$ and $1.01 \pm 0.13 \mu \mathrm{mol} / \mathrm{L}$, respectively (Table 2 ).
TABLE 1: Cytotoxic effect of HHC and HHDC evaluated by means of ATP liberation.

\begin{tabular}{lcc}
\hline \multirow{2}{*}{ Concentration $(\mu \mathrm{mol} / \mathrm{L})$} & \multicolumn{2}{c}{ ATP liberation $(\mathrm{nmol} / \mathrm{L})$} \\
& HHC & HHDC \\
\hline 0 & $13.53 \pm 1.59$ & $12.38 \pm 1.22$ \\
1 & $12.63 \pm 1.67$ & $11.99 \pm 1.24$ \\
10 & $10.25 \pm 0.37$ & $12.57 \pm 1.14$ \\
100 & $7.91 \pm 0.41$ & $12.94 \pm 1.01$ \\
\hline
\end{tabular}

The data express ATP liberation from 30,000 neutrophils.

0 : untreated neutrophils, $1-100 \mu \mathrm{mol} / \mathrm{L}$ : treated by HHC or HHDC, total $(159 \pm 12 \mathrm{nmol} / \mathrm{L})$ represents ATP content as determined immediately after complete neutrophil destruction. Mean $\pm \operatorname{SEM}, n=6$.

TABle 2: Doses of the compounds tested producing 50\% inhibition of control extracellular CL and intracellular CL of human neutrophils and cell-free CL system.

\begin{tabular}{lcc}
\hline Chemiluminescence & $\begin{array}{c}\mathrm{HHC} \\
\mathrm{EC}_{50}(\mu \mathrm{mol} / \mathrm{L})\end{array}$ & $\begin{array}{c}\mathrm{HHDC} \\
\mathrm{EC}_{50}(\mu \mathrm{mol} / \mathrm{L})\end{array}$ \\
\hline Extracellular & $1.04 \pm 0.20$ & $1.01 \pm 0.13$ \\
Intracellular & $5.24 \pm 0.57$ & $>100$ \\
Cell free & $0.59 \pm 0.01$ & $2.47 \pm 0.04$ \\
\hline
\end{tabular}

Human isolated neutrophils $\left(5 \times 10^{5} /\right.$ sample $)$ were stimulated with PMA $(0.05 \mu \mathrm{mol} / \mathrm{L})$ at $37^{\circ} \mathrm{C}$, in the presence of HHC or HHDC $(0.01-100 \mu \mathrm{mol} / \mathrm{L})$. Extra- and intracellular ROS production were measured by isoluminol-/ luminol-enhanced CL. In the cell-free system (luminol, horseradish peroxidase, and hydrogen peroxide), CL responses were measured in the presence of HHC or HHDC $(1,10$, or $100 \mu \mathrm{mol} / \mathrm{L})$ at $37^{\circ} \mathrm{C}$. Percentage inhibition was calculated on the basis of integrated values of CL over $1800 \mathrm{~s}$ (extra- and intracellular CL) and of cell-free CL over 10 minutes. Mean \pm SEM, $n=3-8$. Control values given in RLU $\times$ seconds were $5.8 \times 10^{6} \pm 1.4 \times 10^{6}$ for extracellular CL, $5 \times 10^{5} \pm 0.5 \times 10^{4}$ for intracellular $\mathrm{CL}$, and $3.8 \times 10^{5} \pm 0.18 \times 10^{4}$ for cell-free CL.

While HHC in the concentration scale of $0.01-100 \mu \mathrm{mol} / \mathrm{L}$ decreased significantly intracellular ROS production $\left(\mathrm{IC}_{50}\right.$ : $5.24 \pm 0.57 \mu \mathrm{mol} / \mathrm{L}$ ), HHDC was slightly effective only in the highest concentration tested (Figure 4 and Table 2).

3.3. Effects of HHC and HHDC on Cell-Free Chemiluminescence System. Further we tested the participation of direct antioxidant activity of HHC and HHDC in a cell-free CL system consisting of luminol, horseradish peroxidase, and 


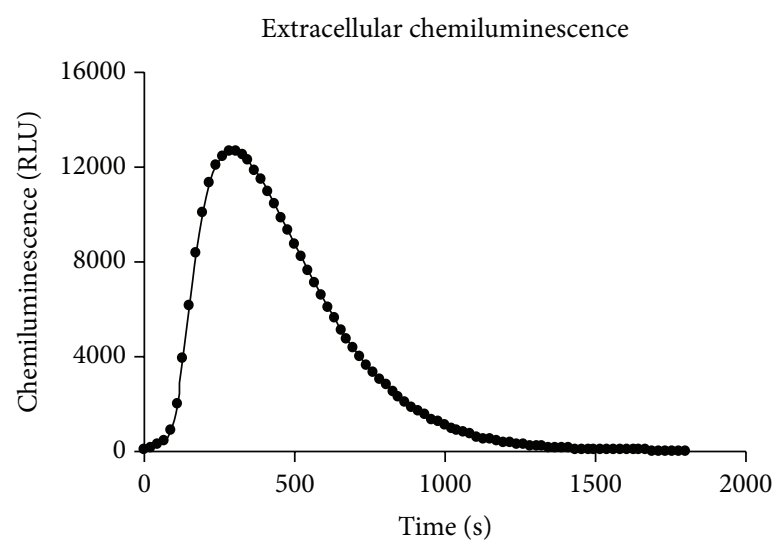

(a)

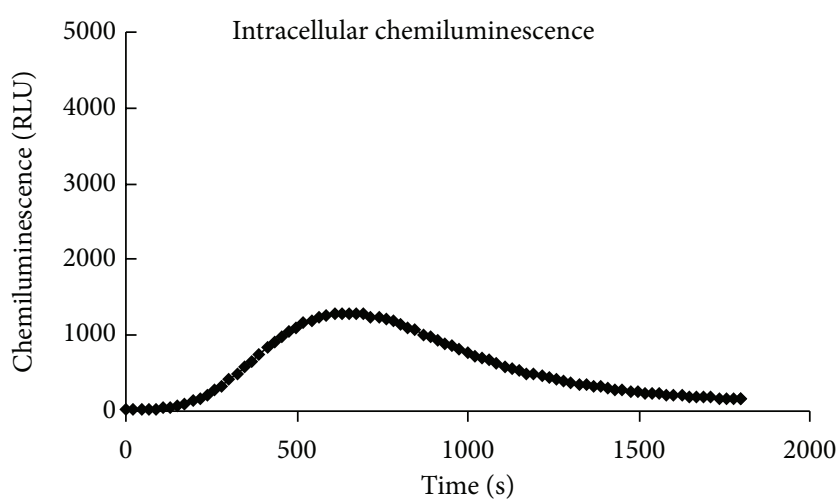

(b)

FIgURE 2: Kinetic curves of extra- and intracellular ROS formation in PMA stimulated human neutrophils. Human isolated neutrophils $\left(5 \times 10^{5} / \mathrm{sample}\right)$ were stimulated with PMA $(0.05 \mu \mathrm{mol} / \mathrm{L})$ at $37^{\circ} \mathrm{C}$. Extra- and intracellular ROS production were measured by isoluminol-/ luminol-enhanced chemiluminescence over $1800 \mathrm{~s}$. Kinetic curves are representative of 6 donors. RLU: relative light units.

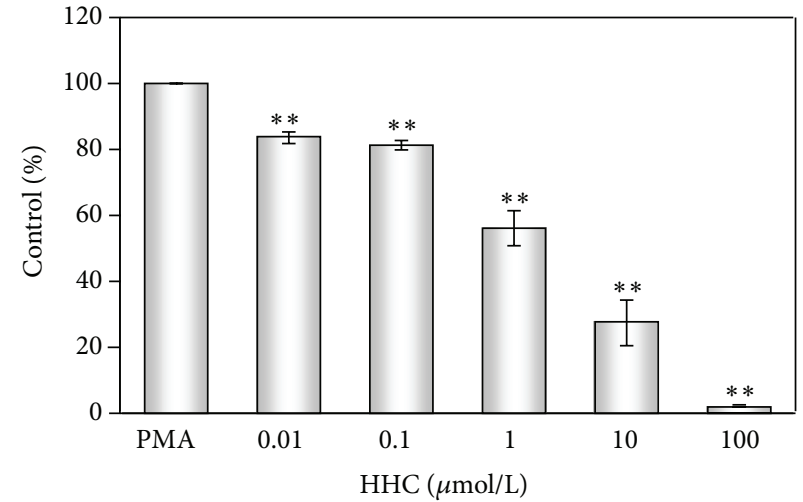

(a)

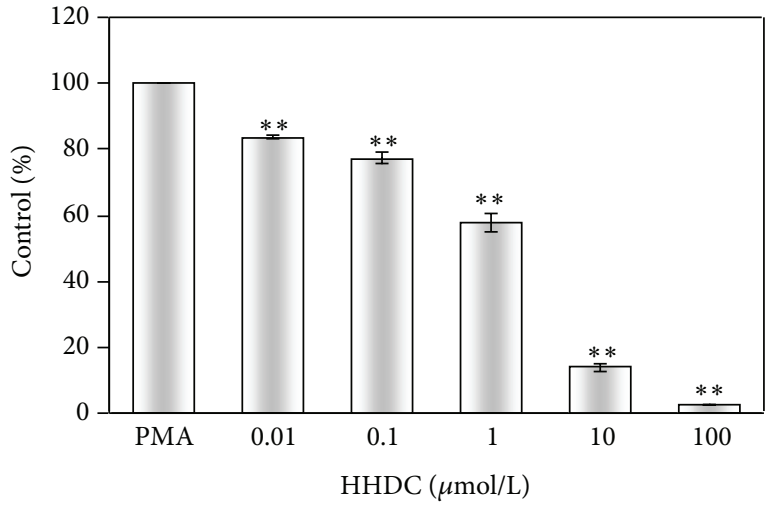

(b)

FIGURE 3: Effect of HHC and HHDC on PMA stimulated extracellular chemiluminescence of human neutrophils. Human isolated neutrophils $\left(5 \times 10^{5} / \mathrm{sample}\right)$ were stimulated with PMA $(0.05 \mu \mathrm{mol} / \mathrm{L})$ at $37^{\circ} \mathrm{C}$ in the presence of HHC or HHDC $(0.01-100 \mu \mathrm{mol} / \mathrm{L})$. Extracellular ROS production was measured in the presence of HRP by isoluminol-enhanced chemiluminescence over $1800 \mathrm{~s}$. The values were calculated as percentage of stimulated (PMA) control, on the basis of integrated values of chemiluminescence over $1800 \mathrm{~s}$. Control value given in RLU $\times$ seconds was $5.8 \times 10^{6} \pm 1.4 \times 10^{6}$. Mean $\pm \mathrm{SEM}, n=6 .{ }^{* *} P<0.01$ as compared with the control (PMA) in the absence of the substances tested.

hydrogen peroxide. Our results showed an effective inhibition of chemiluminescence generated by cell-free system with HHC $\left(\mathrm{IC}_{50}: 0.59 \pm 0.01\right)$ and HHDC $\left(\mathrm{IC}_{50}: 2.47 \pm 0.04\right)$ (Table 2).

3.4. Effects of HHC and HHDC on PKC Activity and on the Phosphorylation of the PKC Isoforms (PKC $\alpha, \beta I I$, and $\delta)$. Stimulation of neutrophils with phorbol esters activates the PKC isoforms $\alpha, \beta \mathrm{II}$, and $\delta$, which are involved in the oxidative burst as key activators of NADPH oxidase. First we analysed whether modulation of PKC activity by HHC or HHDC might mediate their inhibitory effect on PMA stimulated ROS production. HHC in the concentrations of 1,10 , and $100 \mu \mathrm{mol} / \mathrm{L}$ significantly decreased PKC activity to $87.7 \pm 4.2 \%, 74.8 \pm 6.3 \%$, and $46.3 \pm 1.8 \%$, respectively. On the other hand, HHDC did not significantly influence PKC activity (Figure 5). Since the PKC activity assay determined all PKC isoforms $(\alpha, \beta, \gamma, \delta, \varepsilon, \mu, \zeta$, and $\theta)$, we further specified the effect of HHC and HHDC on phosphorylation of PKC $\alpha$, $\beta \mathrm{II}$, and $\delta$.

After PMA stimulation, we observed increased phosphorylation of $\mathrm{PKC} \alpha, \beta \mathrm{II}$, and $\delta$ in comparison with unstimulated human neutrophils. Treatment with HHC or HHDC in the concentrations of 10 and $100 \mu \mathrm{mol} / \mathrm{L}$ resulted in decrease in the level of PKC $\alpha, \beta \mathrm{II}$ as compared to those of control but did not affect phosphorylation of PKC $\delta$ (Figures 6 and 7).

\subsection{Effects of HHC and HHDC on the Phosphorylation of the} NADPH Oxidase Component $p 40^{\text {phox }}$. Recently, the selective role for $\mathrm{p} 40^{\text {phox }}$ in intracellular ROS production was reported $[10,13]$. We studied whether the observed inhibition of intracellular ROS production, particularly by $\mathrm{HHC}$, might 


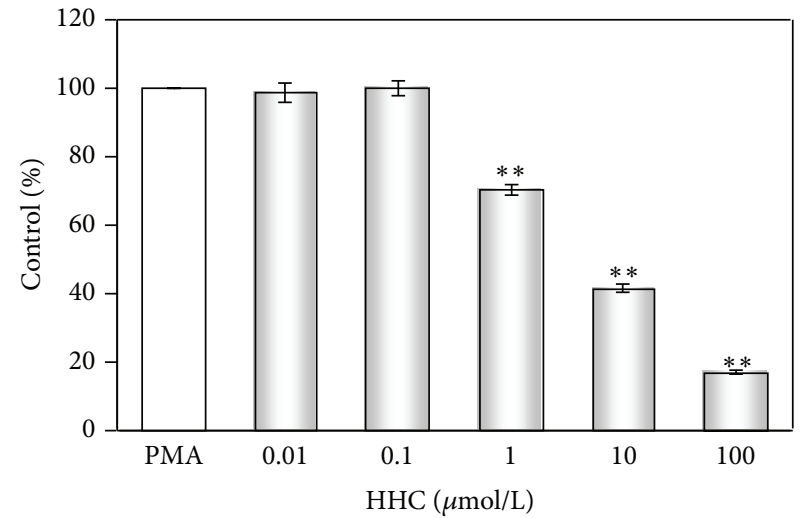

(a)

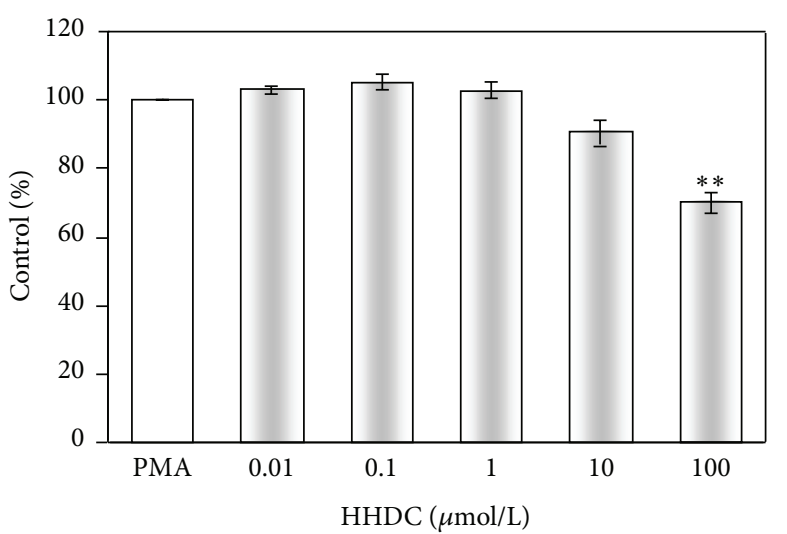

(b)

FIGURE 4: Effect of HHC and HHDC on PMA stimulated intracellular chemiluminescence of human neutrophils. Human isolated neutrophils $\left(5 \times 10^{5} /\right.$ sample) were stimulated with PMA $(0.05 \mu \mathrm{mol} / \mathrm{L})$ at $37^{\circ} \mathrm{C}$ in the presence of HHC or HHDC $(0.01-100 \mu \mathrm{mol} / \mathrm{L})$. Intracellular ROS production was measured in the presence of superoxide dismutase and catalase by luminol-enhanced chemiluminescence over $1800 \mathrm{~s}$. The values were calculated as percentage of stimulated (PMA) control, on the basis of integrated values of chemiluminescence over $1800 \mathrm{~s}$. Control value given in RLU $\times$ seconds was $5 \times 10^{5} \pm 0.5 \times 10^{4}$. Mean $\pm \mathrm{SEM}, n=6 .{ }^{* *} P<0.01,{ }^{*} P<0.05$ as compared with the control (PMA) in the absence of the substances tested.

be connected with its effect on phosphorylation of $440^{\text {phox }}$ subunit in PMA stimulated human neutrophils. As shown in Figure 8, PMA increased phosphorylation of $40^{\text {phox }}$ subunit, yet $\mathrm{HHC}$ and HHDC failed to influence it.

\section{Discussion}

Regulation of neutrophil activity is one of the important factors in achieving host defense and avoiding tissue-damaging inflammation. Recently, great attention has been devoted to polyphenols of natural origin as well as to their synthetic derivatives. Many of them were found to possess effects which could be used in prevention and support therapy of chronic inflammatory diseases [30-35]. Previously, we have suggested that different effects of phenylcoumarin derivatives HHC and HHDC on phagocyte functions may be due to their diverse free radical scavenging properties and lipophilicity features. Further, we indicated that the ability of HHC and HHDC to reduce oxidant production in neutrophils might be connected with inhibition of NADPH oxidase activity, via decrease of PKC activation [23]. In the present study we specified the site of HHC and HHDC action on ROS generation and considered some possible molecular mechanisms linking regulation of oxidant production.

Our results showed that neutrophils activated by PMA responded by an oxidant production composed of both extra- and intracellular component of chemiluminescence. We found the extracellular ROS production to be predominant, as also demonstrated by Björnsdottir et al. [13] and Dahlgren and Karlsson [36]; however, in comparison with their results we observed a higher ratio between oxidants produced extra- and intracellularly, in favour of the former. HHC and HHDC were potent inhibitors of extracellular ROS production in human neutrophils stimulated with PMA. While HHDC reduced intracellular ROS generation only in the highest concentration tested, HHC possessed significant inhibitory effect in a concentration-dependent manner. The inhibition of both extra- and intracellular oxidant production indicated a possible interference of HHC and HHDC with ROS (scavenging activity) as well as with signalling events resulting in ROS production.

The effective inhibition of cell-free system chemiluminescence by both compounds tested (Table 2) showed that free radical scavenging properties of HHC and HHDC play an important role in the reduction of both extra- and intracellular oxidant production. The results obtained in cellfree system also suggest they interfere with peroxidase, since luminol reaction is highly dependent on the participation of myeloperoxidase. The possibility of this interaction with peroxidase is supported by findings of Kabeya et al. [37] and Andrade et al. [38] who demonstrated the inhibitory effect of 3-phenylcoumarin hydroxylated derivatives on horseradish peroxidase catalytic activity. The inhibitory effect of stilbene derivatives on myeloperoxidase release was described also by Pečivová et al. [39].

The relationships between antioxidant activities and chemical structures of coumarin derivatives are important factors which may influence the oxidant production in vitro and in vivo [1, 23, 38, 40-42]. Both coumarines tested, HHC and HHDC, have a similar structure: a hydroxyl group at C7 position at ring $\mathrm{A}$ and a hydroxyl group at $\mathrm{C} 4^{\prime}$ position at ring $\mathrm{B}$. While HHC has an unsaturated bond between $\mathrm{C} 3$ and $\mathrm{C} 4$ at ring $\mathrm{C}, \mathrm{HHDC}$ fails to possess it (Figure 1). Our results indicate that the inhibitory effect of HHC and HHDC on PMA stimulated extracellular ROS generation in neutrophils is probably not dependent on the presence of a double bond between $\mathrm{C} 3$ and $\mathrm{C} 4$ at ring $\mathrm{C}$. On the other hand, the more pronounced inhibition of intracellular ROS production by HHC indicates the requirement of an unsaturated 3-, 4binding site at ring $\mathrm{C}$ for this inhibitory effect. 


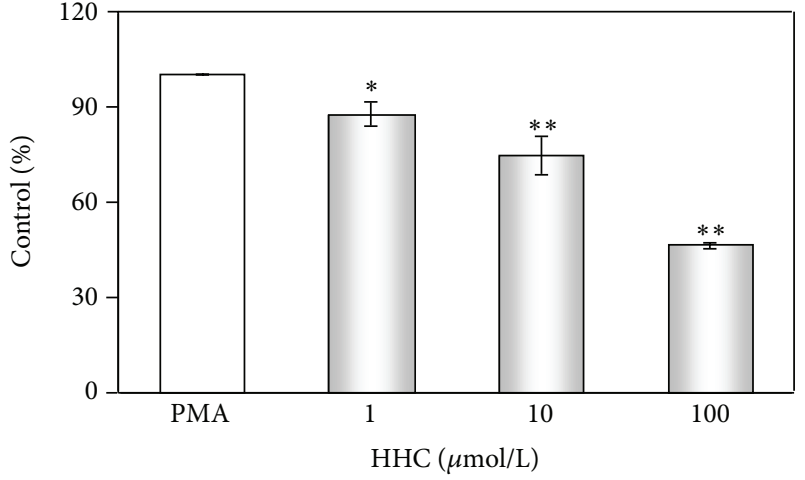

(a)

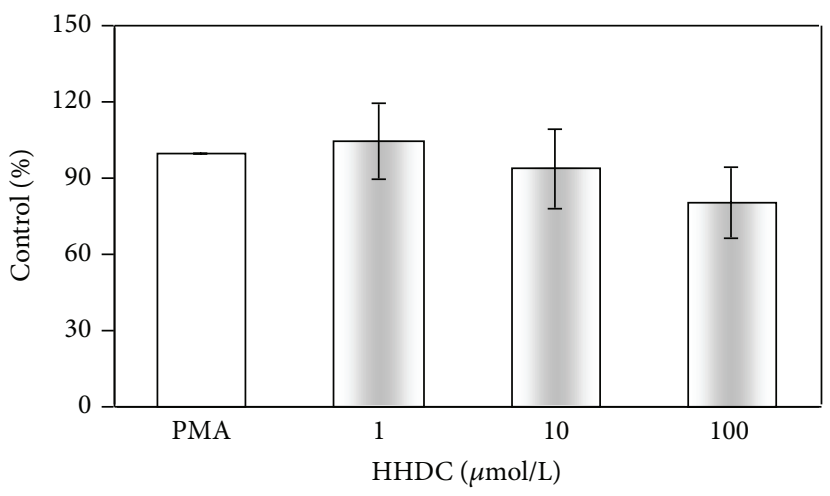

(b)

FIGURE 5: Effect of HHC and HHDC on PKC activity. Human isolated neutrophils $\left(5 \times 10^{5} / \mathrm{mL}\right)$ were incubated for 30 min with HHC or $\operatorname{HHDC}(1,10$, and $100 \mu \mathrm{mol} / \mathrm{L})$ and stimulated with PMA $(0.15 \mu \mathrm{mol} / \mathrm{L})$ at $37^{\circ} \mathrm{C}$ for $3 \mathrm{~min}$. PKC activity was measured by ELISA kit in the supernatant of cell lysate. The values were calculated as percentage of stimulated (PMA) control. Control value given as relative kinase activity $(450 \mathrm{~nm})$ per $1 \mathrm{mg}$ of protein was $9708 \pm 1168$. Mean $\pm \mathrm{SEM}, n=8 .{ }^{* *} P<0.01,{ }^{*} \mathrm{P}<0.05$ as compared with the control (PMA) in the absence of the substances tested.

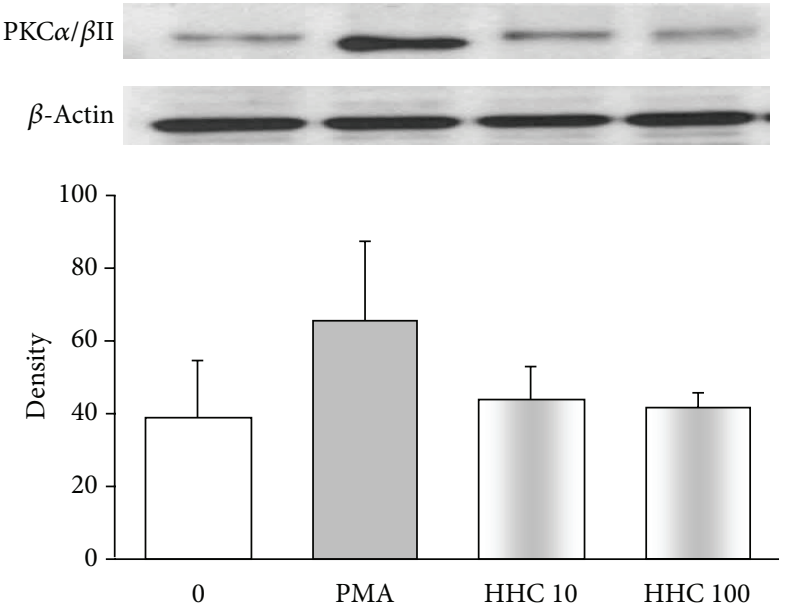

(a)
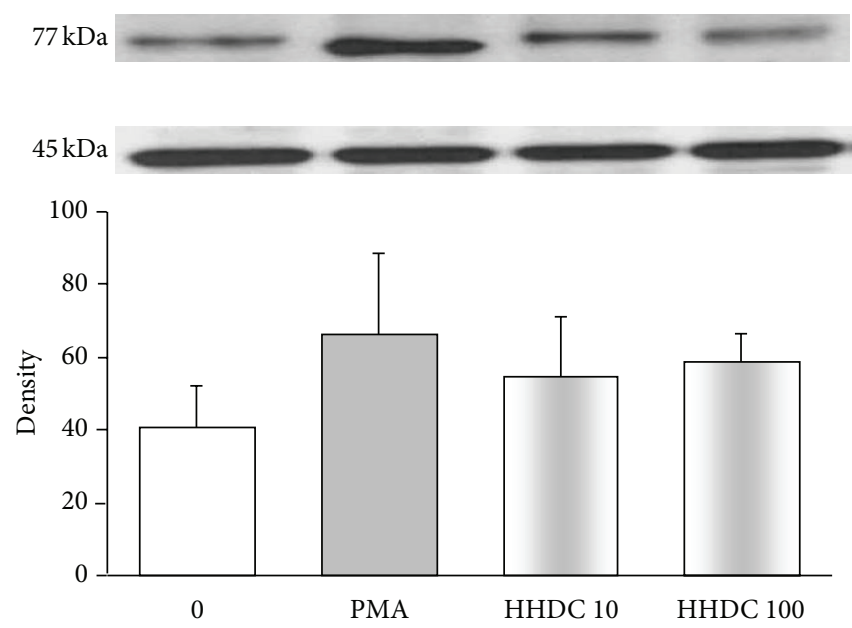

(b)

FIGURE 6: PKC phosphorylation in PMA stimulated human neutrophils treated with 10 and $100 \mu \mathrm{mol} / \mathrm{L}$ HHC or HHDC. Human isolated neutrophils $\left(5 \times 10^{6}\right.$ cells $)$ were incubated at $37^{\circ} \mathrm{C}$ with $\mathrm{HHC}$ or HHDC $(10$ or $100 \mu \mathrm{mol} / \mathrm{L})$ for $1 \mathrm{~min}$, prior to addition of PMA $(0.15 \mu \mathrm{mol} / \mathrm{L})$. Cell lysates were prepared, and the protein levels of PKC isoenzymes ( $\alpha$ and $\beta \mathrm{II}$ ) were analyzed by Western blotting and detected by PhosphoPKC $\alpha / \beta$ II (Thr638/641) Antibody. The data are evaluated as optical density of PKC corrected to optical density of the corresponding $\beta$-actin band. Mean \pm SEM, $n=8$ (the data are representative of 4 donors performed in 2 separate experiments).

Polyphenols were reported to affect cell functions by modifying plasma membrane structure and physical characteristics, such as fluidity and electrical properties. These effects can be observed both when polyphenols are adsorbed on the membrane and when they are inserted into the bilayer [43]. The low effect of HHDC on intracellular ROS generation might be explained by the lower values of the partition coefficient of HHDC compared to that of HHC and thus the more efficient penetration of HHC into the membrane than that of the less lipophilic HHDC, as shown by our earlier published findings [23].

In biological systems, ROS are generated by a number of enzymatic systems, and modifications of plasma membrane structure can result in functional changes, including the activity of membrane-associated enzymes and the modulation of signal transduction $[7,43]$.

Inhibition of PKC or downregulation of its intracellular expression and activity has been proposed as an important mechanism of the antioxidant effect of polyphenols [7, 27, $35,44,45]$. We found that HHC, unlike HHDC, effectively decreased intracellular oxidant production involved in the regulation of neutrophil function, and we thus supposed its interaction to occur at PKC level. Since we observed a significant reduction of PKC activity by HHC, we further specified its effect on $\mathrm{PKC} \alpha, \beta \mathrm{II}$ phosphorylation. Inhibition of $\mathrm{PKC}$ activity and $\mathrm{PKC} \alpha$, $\beta \mathrm{II}$ phosphorylation by $\mathrm{HHC}$ only, 

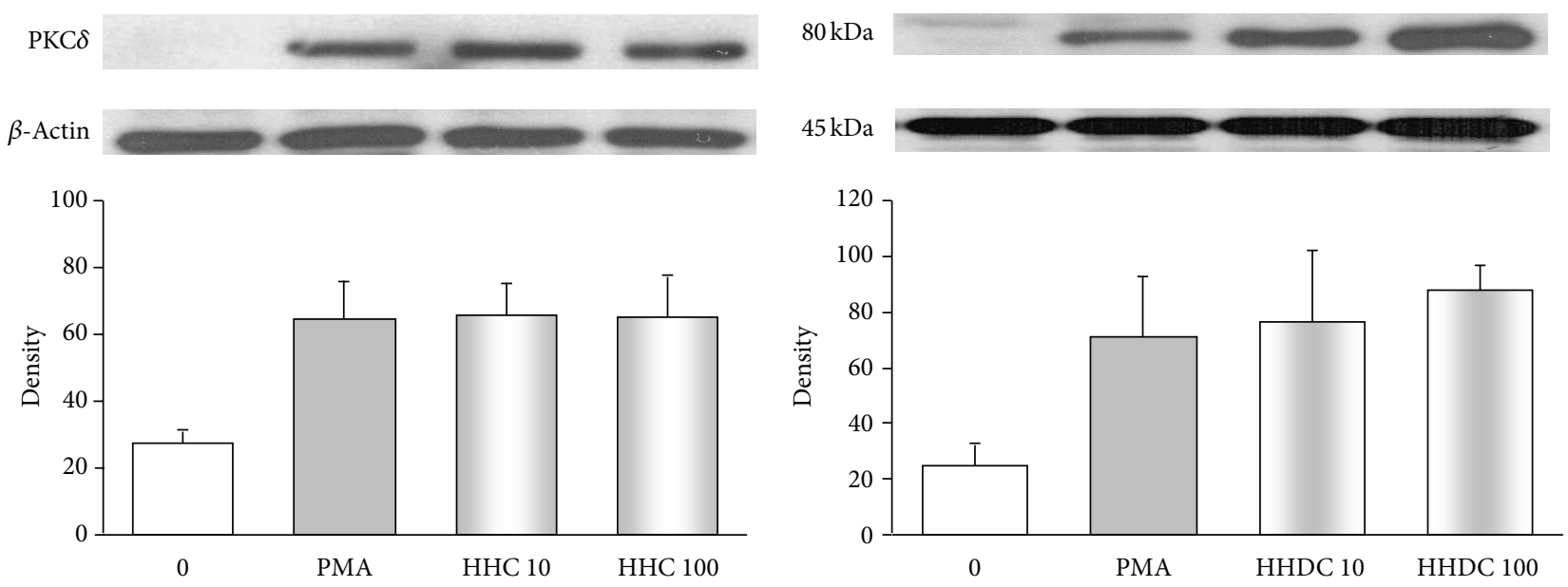

(a)

(b)

FIGURE 7: PKC phosphorylation in PMA stimulated human neutrophils treated with 10 and $100 \mu \mathrm{mol} / \mathrm{L}$ HHC or HHDC. Human isolated neutrophils $\left(5 \times 10^{6}\right.$ cells) were incubated at $37^{\circ} \mathrm{C}$ with $\mathrm{HHC}$ or HHDC $(10$ or $100 \mu \mathrm{mol} / \mathrm{L})$ for $1 \mathrm{~min}$, prior to addition of PMA $(0.15 \mu \mathrm{mol} / \mathrm{L})$. Cell lysates were prepared, and the protein level of PKC isoenzyme $\delta$ was analyzed by Western blotting and detected by Phospho-PKC $\delta$ (Thr505) Antibody. The data are evaluated as optical density of PKC corrected to optical density of the corresponding $\beta$-actin band. Mean \pm SEM, $n=8$ (the data are representative of 4 donors performed in 2 separate experiments).

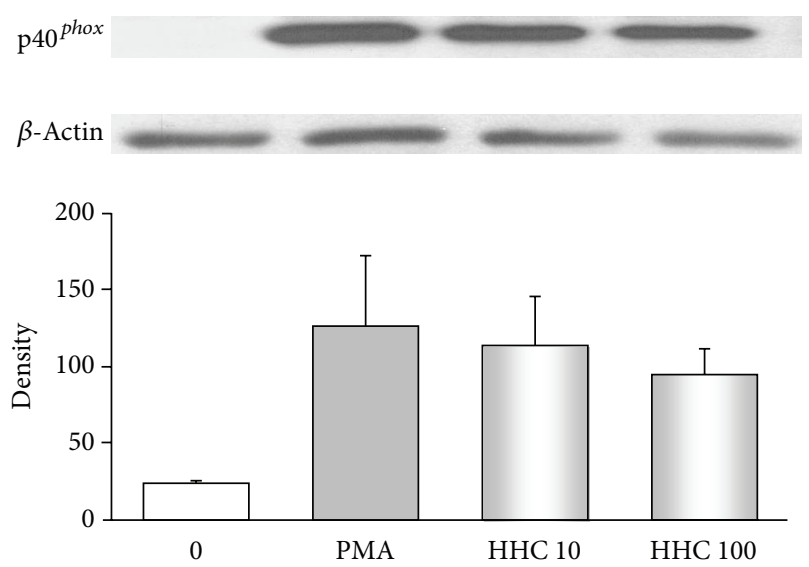

(a)
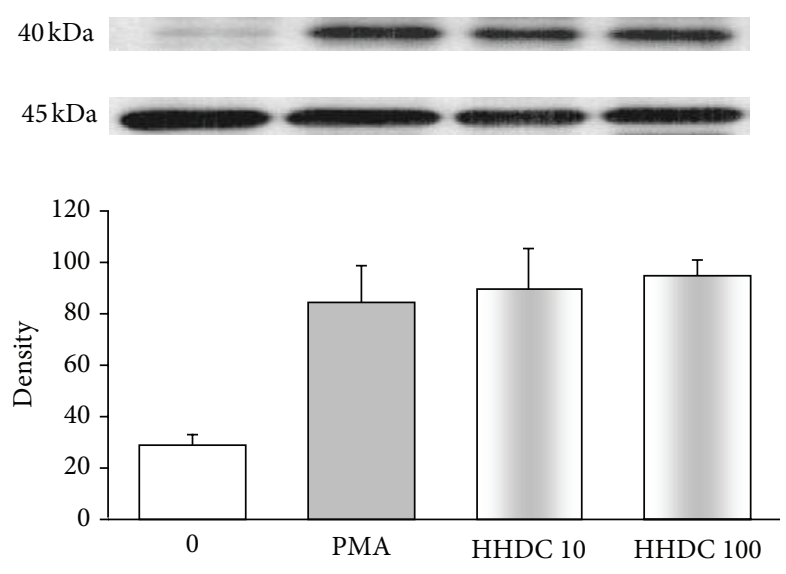

(b)

FIGURE 8: Phosphorylation of the NADPH oxidase component $440^{\text {phox }}$ in PMA stimulated human neutrophils treated with 10 and $100 \mu$ mol/L HHC or HHDC. Human isolated neutrophils $\left(5 \times 10^{6}\right.$ cells $)$ were incubated at $37^{\circ} \mathrm{C}$ with $\mathrm{HHC}$ or HHDC $(10$ or $100 \mu \mathrm{mol} / \mathrm{L})$ for $1 \mathrm{~min}$, prior to addition of PMA $(0.15 \mu \mathrm{mol} / \mathrm{L})$. Cell lysates were prepared, and the protein level $\mathrm{p} 40^{\text {phox }}$ subunit was analyzed by Western blotting and detected by Phospho-p40 phox (Thr 154) Antibody. The results are evaluated as optical density of p $40^{\text {phox }}$ corrected to optical density of the corresponding $\beta$-actin band. Mean \pm SEM, $n=8$ (the data are representative of 4 donors performed in 2 separate experiments).

indicates that the presence of the double bond between $\mathrm{C} 3$ and $\mathrm{C} 4$ at ring $\mathrm{C}$ is necessary for this effect. Structure dependence of the inhibitory effect of polyphenolic antioxidants on signal transduction enzymes, such as PKC, was found also by Varga et al. [40]. Although a specific role for PKC $\delta$ in the PMA-dependent intracellular activation process was reported [22], we did not observe any effect of coumarines tested on phosphorylation of PKC $\delta$.

One of the cytosolic components of the NADPH oxidase, $\mathrm{p} 40^{\text {phox }}$, which is specifically translocated to intracellular phagosomal and granule membranes, was also indicated as a further determining factor for intracellular ROS production
$[10,12]$. Moreover, a reduction of $\mathrm{p} 40^{\text {phox }}$ phosphorylation by PKC inhibitors was found by Bouin et al. [46] and Someya et al. [47]. Our results, however, showed that in PMA stimulated neutrophils reduction of intracellular ROS generation and PKC activity by HHC was not associated with inhibition of phosphorylation of the NADPH oxidase subunit $\mathrm{p} 40^{\text {phox }}$.

\section{Conclusion}

We extended our previous findings about the actions of the coumarine derivatives HHC and HHDC on the activity 
of human neutrophils by investigating the influence of extra- and intracellular ROS formation and some possible molecular mechanisms affecting the regulation of oxidant production. The presented results suggest that, in pathological processes in which neutrophils are involved, HHDC may act predominantly as a potent inhibitor/scavenger of extracellularly produced ROS. HHC may act both extra- and intracellularly, and, besides its direct interference with ROS, it may interfere also with the PKC signalling pathway. These findings confirmed our previous assumption that the different effects of the coumarine derivatives tested might be due to their diverse molecular structures, which provides them with different physicochemical and free radical scavenging characteristics.

\section{Conflict of Interests}

The authors state no conflict of interests.

\section{Acknowledgments}

This study was supported by Grants VEGA 2/0010/13, APVV0052-10, and APVV-0315-07. The authors thank Professor Magda Kouřilová-Urbanczik for English language correcting of the paper.

\section{References}

[1] M. E. Riveiro, A. Moglioni, R. Vazquez et al., "Structural insights into hydroxycoumarin-induced apoptosis in U-937 cells," Bioorganic and Medicinal Chemistry, vol. 16, no. 5, pp. 2665-2675, 2008.

[2] F. Belluti, G. Fontana, L. D. Bo, N. Carenini, C. Giommarelli, and F. Zunino, "Design, synthesis and anticancer activities of stilbene-coumarin hybrid compounds: identification of novel proapoptotic agents," Bioorganic and Medicinal Chemistry, vol. 18, no. 10, pp. 3543-3550, 2010.

[3] I. Kostova, S. Bhatia, P. Grigorov et al., "Coumarins as antioxidants," Current Medicinal Chemistry, vol. 18, no. 25, pp. 39293951, 2011.

[4] K. V. Sashidhara, A. Kumar, R. P. Dodda et al., "Coumarintrioxane hybrids: synthesis and evaluation as a new class of antimalarial scaffolds," Bioorganic \& Medicinal Chemistry Letters, vol. 22, no. 12, pp. 3926-3930, 2012.

[5] R. Ramasamy, M. Maqbool, A. L. Mohamed, and R. M. Noah, "Elevated neutrophil respiratory burst activity in essential hypertensive patients," Cellular Immunology, vol. 263, no. 2, pp. 230-234, 2010.

[6] M. Ciz, P. Denev, M. Kratchanova, O. Vasicek, G. Ambrozova, and A. Lojek, "Flavonoids inhibit the respiratory burst of neutrophils in mammals," Oxidative Medicine and Cellular Longevity, vol. 2012, Article ID 181295, 6 pages, 2012.

[7] A. I. Khlebnikov, I. A. Schepetkin, N. G. Domina, L. N. Kirpotina, and M. T. Quinn, "Improved quantitative structureactivity relationship models to predict antioxidant activity of flavonoids in chemical, enzymatic, and cellular systems," Bioorganic and Medicinal Chemistry, vol. 15, no. 4, pp. 17491770, 2007.

[8] K. A. Gauss, L. K. Nelson-Overton, D. W. Siemsen, Y. Gao, F. R. DeLeo, and M. T. Quinn, "Role of NF- $\kappa$ B in transcriptional regulation of the phagocyte NADPH oxidase by tumor necrosis factor- $\alpha$, Journal of Leukocyte Biology, vol. 82, no. 3, pp. 729741, 2007.

[9] H. Raad, M. H. Paclet, T. Boussetta et al., "Regulation of the phagocyte NADPH oxidase activity: phosphorylation of gp9lphox/NOX2 by protein kinase $\mathrm{C}$ enhances its diaphorase activity and binding to Rac2, p67phox, and p47phox," FASEB Journal, vol. 23, no. 4, pp. 1011-1022, 2009.

[10] J. Bylund, K. L. Brown, C. Movitz, C. Dahlgren, and A. Karlsson, "Intracellular generation of superoxide by the phagocyte NADPH oxidase: how, where, and what for?" Free Radical Biology and Medicine, vol. 49, no. 12, pp. 1834-1845, 2010.

[11] A. Karlsson and C. Dahlgren, "Assembly and activation of the neutrophil NADPH oxidase in granule membranes," Antioxidants and Redox Signaling, vol. 4, no. 1, pp. 49-60, 2002.

[12] J. D. Matute, A. A. Arias, N. A. M. Wright et al., "A new genetic subgroup of chronic granulomatous disease with autosomal recessive mutations in p40phox and selective defects in neutrophil NADPH oxidase activity," Blood, vol. 114, no. 15, pp. 3309-3315, 2009.

[13] H. Björnsdottir, D. Granfeldt, A. Welin, J. Bylund, and A. Karlsson, "Inhibition of phospholipase A2 abrogates intracellular processing of NADPH-oxidase derived reactive oxygen species in human neutrophils," Experimental Cell Research, vol. 319, no. 5, pp. 761-774, 2013.

[14] G. Nimeri, M. Majeed, H. Elwing, L. Öhman, J. Wetterö, and T. Bengtsson, "Oxygen radical production in neutrophils interacting with platelets and surface-immobilized plasma proteins: role of tyrosine phosphorylation," Journal of Biomedical Materials Research A, vol. 67, no. 2, pp. 439-447, 2003.

[15] J. El-Benna, P. M. C. Dang, M. A. Gougerot-Pocidalo, J. C. Marie, and F. Braut-Boucher, "p47phox, the phagocyte NADPH oxidase/NOX2 organizer: structure, phosphorylation and implication in diseases," Experimental and Molecular Medicine, vol. 41, no. 4, pp. 217-225, 2009.

[16] N. J. Hong, G. B. Silva, and J. L. Garvin, "PKC- $\alpha$ mediates flowstimulated superoxide production in thick ascending limbs," American Journal of Physiology-Renal Physiology, vol. 298, no. 4, pp. F885-F891, 2010.

[17] H. M. Korchak, L. B. Dorsey, H. Li, D. Mackie, and L. E. Kilpatrick, "Selective roles for $\alpha$-PKC in positive signaling for $\mathrm{O}_{2}$-generation and calcium mobilization but not elastase release in differentiated HL60 cells," Biochimica et Biophysica Acta, vol. 1773, no. 3, pp. 440-449, 2007.

[18] J. B. Nixon and L. C. McPhail, "Protein kinase C (PKC) isoforms translocate to triton-insoluble fractions in stimulated human neutrophils: correlation of conventional PKC with activation of NADPH oxidase," Journal of Immunology, vol. 163, no. 8, pp. 4574-4582, 1999.

[19] A. Bertram and K. Ley, "Protein kinase C isoforms in neutrophil adhesion and activation," Archivum Immunologiae et Therapiae Experimentalis, vol. 59, no. 2, pp. 79-87, 2011.

[20] J. Vrba, Z. Dvořák, J. Ulrichová, and M. Modrianský, "Conventional protein kinase $\mathrm{C}$ isoenzymes undergo dephosphorylation in neutrophil-like HL-60 cells treated by chelerythrine or sanguinarine," Cell Biology and Toxicology, vol. 24, no. 1, pp. 39$53,2008$.

[21] L. E. Kilpatrick, S. Sun, H. Li, T. C. Vary, and H. M. Korchak, "Regulation of TNF-induced oxygen radical production in human neutrophils: role of $\delta$-PKC, Journal of Leukocyte Biology, vol. 87, no. 1, pp. 153-164, 2010. 
[22] G. E. Brown, M. Q. Stewart, H. Liu, V. L. Ha, and M. B. Yaffe, "A novel assay system implicates PtdIns(3,4)P2, PtdIns(3)P, and $\mathrm{PKC} \delta$ in intracellular production of reactive oxygen species by the NADPH oxidase," Molecular Cell, vol. 11, no. 1, pp. 35-47, 2003.

[23] K. Drábiková, T. Perečko, R. Nosál' et al., "Different effect of two synthetic coumarin-stilbene hybrid compounds on phagocyte activity," Neuroendocrinology Letters, vol. 31, pp. 73-78, 2010.

[24] V. Jančinová, T. Perečko, R. Nosál’, D. Košt’álová, K. Bauerová, and K. Drábiková, "Decreased activity of neutrophils in the presence of diferuloylmethane (curcumin) involves protein kinase C inhibition," European Journal of Pharmacology, vol. 612, pp. 161-166, 2009.

[25] R. Nosál', T. Perečko, V. Jančinová, K. Drábiková, J. Harmatha, and K. Sviteková, "Naturally appearing N-feruloylserotonin isomers suppress oxidative burst of human neutrophils at the protein kinase C level," Pharmacological Reports, vol. 63, pp. 790-798, 2011.

[26] K. Drábiková, T. Perečko, R. Nosál et al., "Glucomannan reduces neutrophil free radical production in vitro and in rats with adjuvant arthritis," Pharmacological Research, vol. 59, pp. 399403, 2009.

[27] V. Jančinová, T. Perečko, R. Nosál', J. Harmatha, J. Šmidrkal, and K. Drábiková, "The natural stilbenoid pinosylvin and activated neutrophils: effects on oxidative burst, protein kinase C, apoptosis and efficiency in adjuvant arthritis," Acta Pharmacologica Sinica, vol. 33, pp. 1285-1292, 2012.

[28] K. Drábiková, V. Jančinová, R. Nosál', J. Pečivová, T. Mačičková, and P. Turčáni, "Inibitory effect of stobadine on FMLP-induced chemiluminescence in human whole blood and isolated polymorphonuclear leukocytes," Luminescence, vol. 22, pp. 67-71, 2007.

[29] Z. Varga, E. Kosaras, E. Komodi et al., "Effects of tocopherols and $2,2^{\prime}$-carboxyethyl hydroxychromans on phorbol-esterstimulated neutrophils," Journal of Nutritional Biochemistry, vol. 19, no. 5, pp. 320-327, 2008.

[30] D. E. Stevenson and R. D. Hurst, "Polyphenolic phytochemicals-just antioxidants or much more?" Cellular and Molecular Life Sciences, vol. 64, no. 22, pp. 2900-2916, 2007.

[31] K. B. Pandey and S. I. Rizvi, "Plant polyphenols as dietary antioxidants in human health and disease," Oxidative Medicine and Cellular Longevity, vol. 2, no. 5, pp. 270-278, 2009.

[32] M. E. Obrenovich, N. G. Nair, A. Beyaz, G. Aliev, and V. P. Reddy, "The role of polyphenolic antioxidants in health, disease, and aging," Rejuvenation Research, vol. 13, no. 6, pp. 631-643, 2010.

[33] M. Štefek, "Natural flavonoids as potential multifunctional agents in prevention of diabetic cataract," Interdisciplinary Toxicology, vol. 4, no. 2, pp. 69-77, 2011.

[34] T. Perečko, V. Jančinová, K. Drábiková, R. Nosál', and J. Harmatha, "Structure-efficiency relationship in derivatives of stilbene. Comparison of resveratrol, pinosylvin and pterostilbene," Neuroendocrinology Letters, vol. 29, no. 5, pp. 802-805, 2008.

[35] T. Perečko, K. Drábiková, R. Nosál', J. Harmatha, and V. Jančinová, "Pharmacological modulation of activated neutrophils by natural polyphenols," in Recent Research Developments in Pharmacology, S. G. Pandalai, Ed., vol. 2, pp. 27-67, Research Signpost, Trivandrum, India, 2011.

[36] C. Dahlgren and A. Karlsson, "Respiratory burst in human neutrophils," Journal of Immunological Methods, vol. 232, no. 12, pp. 3-14, 1999.
[37] L. M. Kabeya, A. A. de Marchi, A. Kanashiro et al., "Inhibition of horseradish peroxidase catalytic activity by new 3phenylcoumarin derivatives: synthesis and structure-activity relationships," Bioorganic and Medicinal Chemistry, vol. 15, no. 3, pp. 1516-1524, 2007.

[38] M. F. Andrade, L. M. Kabeya, A. E. Azzolini et al., "3Phenylcoumarin derivatives selectively modulate different steps of reactive oxygen species production by immune complexstimulated human neutrophils," International Immunopharmacology, vol. 1, pp. 387-394, 2013.

[39] J. Pečivová, T. Mačičková, J. Harmatha, K. Sviteková, and R. Nosál', "In vitro effect of pinosylvin and pterostilbene on human neutrophils," Interdisciplinary Toxicology, vol. 3, article A73, 2010.

[40] Z. Varga, I. Seres, E. Nagy et al., "Structure prerequisite for antioxidant activity of silybin in different biochemical systems in vitro," Phytomedicine, vol. 13, no. 1-2, pp. 85-93, 2006.

[41] H. C. Lin, S. H. Tsai, C. S. Chen et al., "Structure-activity relationship of coumarin derivatives on xanthine oxidaseinhibiting and free radical-scavenging activities," Biochemical Pharmacology, vol. 75, no. 6, pp. 1416-1425, 2008.

[42] K. F. Devienne, A. F. Cálgaro-Helena, D. J. Dorta et al., "Antioxidant activity of isocoumarins isolated from Paepalanthus bromelioides on mitochondria," Phytochemistry, vol. 68, no. 7, pp. 1075-1080, 2007.

[43] C. G. Fraga, M. Galleano, S. V. Verstraeten, and P. I. Oteiza, "Basic biochemical mechanisms behind the health benefits of polyphenols," Molecular Aspects of Medicine, vol. 31, no. 6, pp. 435-445, 2010.

[44] R. Nosál', T. Perečko, V. Jančinová, K. Drábiková, J. Harmatha, and K. Sviteková, "Suppression of oxidative burst in human neutrophils with the naturally occurring serotonin derivative isomer from Leuzea carthamoides," Neuroendocrinology Letters, vol. 31, pp. 69-72, 2010.

[45] V. Jančinová, T. Perečko, K. Drábiková, R. Nosál', and K. Sviteková, "Piceatannol, a natural analogue of resveratrol, inhibits oxidative burst of human neutrophils," Interdisciplinary Toxicology, vol. 4, pp. A35-A36, 2011.

[46] A. P. Bouin, N. Grandvaux, P. V. Vignais, and A. Fuchs, "p40(phox) is phosphorylated on threonine 154 and serine 315 during activation of the phagocyte NADPH oxidase: implication of a protein kinase C-type kinase in the phosphorylation process," Journal of Biological Chemistry, vol. 273, no. 46, pp. 30097-30103, 1998.

[47] A. Someya, H. Nunoi, T. Hasebe, and I. Nagaoka, "Phosphorylation of p40-phox during activation of neutrophil NADPH oxidase," Journal of Leukocyte Biology, vol. 66, no. 5, pp. 851-857, 1999. 


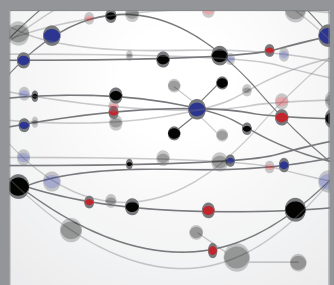

The Scientific World Journal
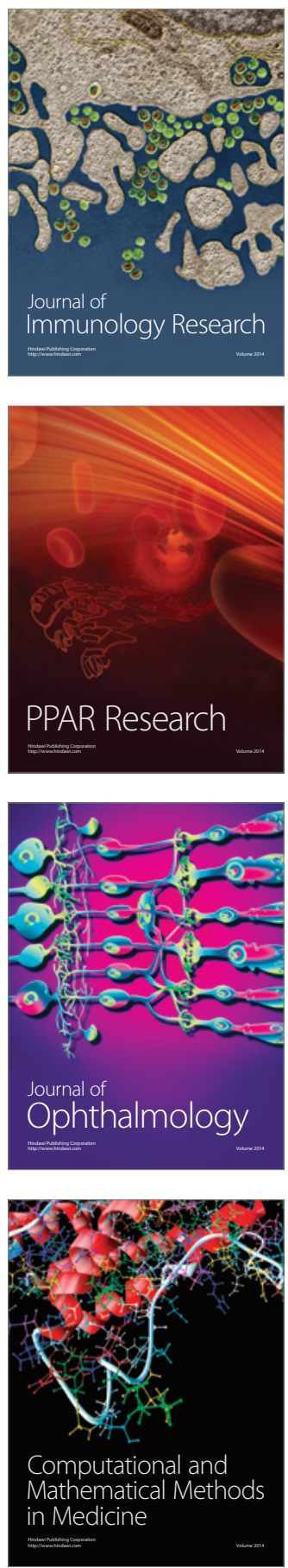

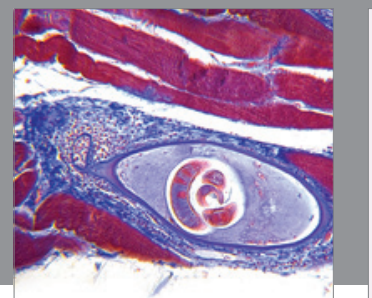

Gastroenterology

Research and Practice
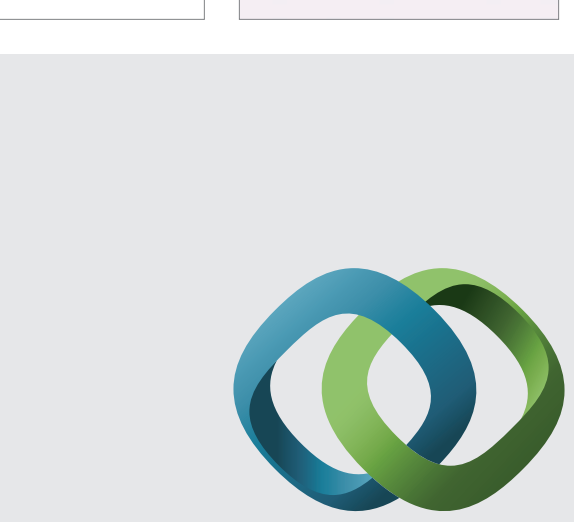

\section{Hindawi}

Submit your manuscripts at

http://www.hindawi.com
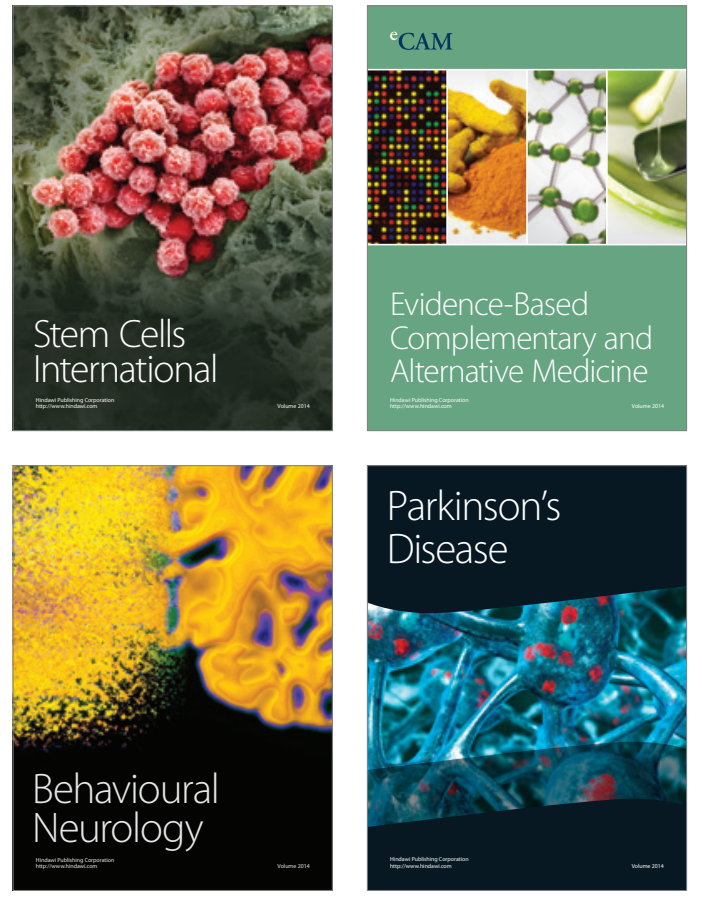
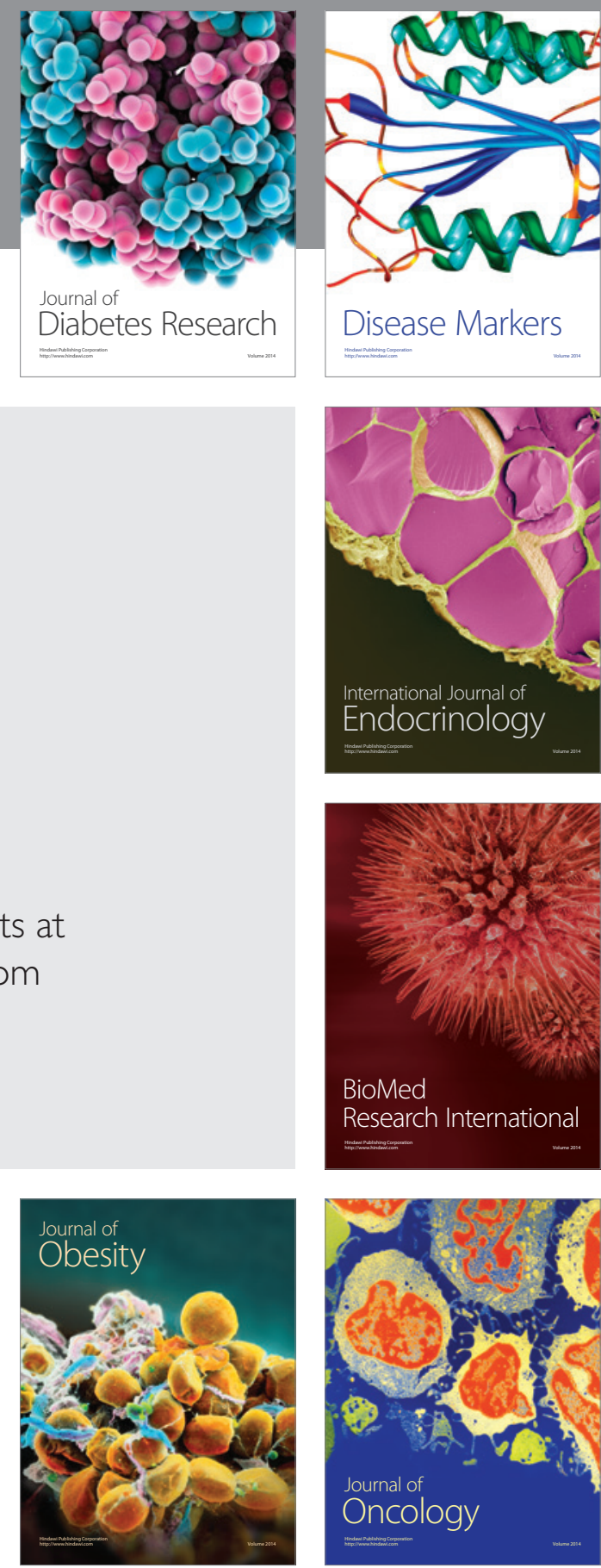

Disease Markers
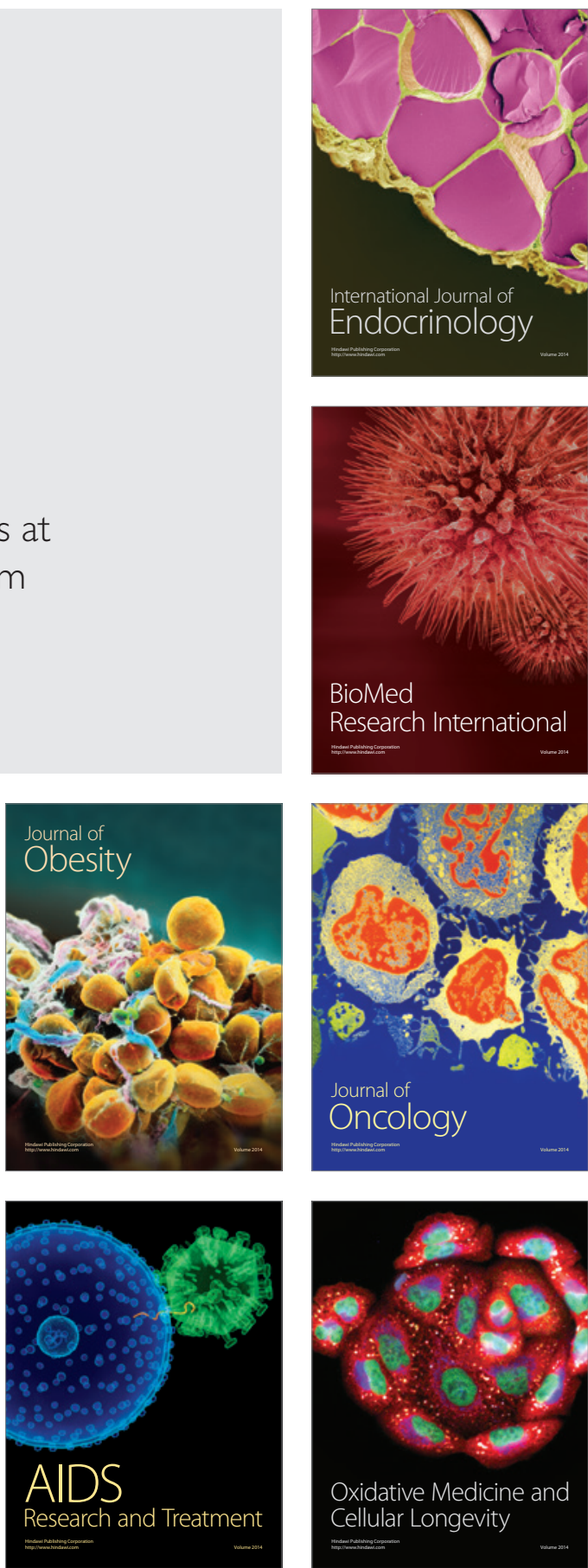